Check for updates

Cite this: RSC Adv., 2019, 9, 16035

\title{
Cytotoxic metabolites from the endophytic fungus Chaetomium globosum $7951 \uparrow$
}

Received 9th April 2019

Accepted 12th May 2019

DOI: $10.1039 /$ c9ra02647a

rsc.li/rsc-advances
Fang Wang,,$^{\mathrm{ab}}$ Wuli Zhao, $\$^{\mathrm{b}}$ Conghui Zhang, ${ }^{\mathrm{b}}$ Shanshan Chang, ${ }^{\mathrm{b}}$ Rongguang Shao, ${ }^{\mathrm{b}}$ Jianguo Xing, ${ }^{c}$ Minghua Chen, (D) *bc Yixuan Zhang (D)*a and Shuyi Si ${ }^{\star b}$

The following compounds were isolated from acetate extracts of Chaetomium globosum 7951 solid cultures: demethylchaetocochin C (1) and chaetoperazine A (3), two new epipolythiodioxopiperazine (ETP) alkaloids, a novel pyridine benzamide, 4-formyl-N-(3'-hydroxypyridin-2'-yl) benzamide (6), and three known ETP derivatives (2, 4, and 5). The structures of these compounds were determined using extensive spectroscopic data analysis. Compounds 1-3, and 6, inhibited the growth of MCF-7, MDA-MB231, $\mathrm{H} 460$ and HCT-8 cells with an $\mathrm{IC}_{50}$ of 4.5 to $65.0 \mu \mathrm{M}$.

\section{Introduction}

Novel bioactive secondary metabolites have been identified in endophytic fungi. ${ }^{1-3}$ The Chaetomium genus, belonging to the Chaetomiaceae family, contains more than 100 species derived from terrestrial and marine habitats. ${ }^{4}$ Chaetomium globosum is a species of the Chaetomium genus. The isolation of the cytotoxic chaetoglobosins A and B was reported by Sekita and coworkers in $1973 .{ }^{5}$ Since then more than 200 metabolites including chaetoglobosins, diketopiperazines, tetramic acids, bis(3-indolyl)-benzoquinones, azaphilones, pyranones, xanthones, anthraquinones, orsellides, steroids, and terpenoids were identified in C. globosum cultures. Some of these metabolites exhibit cytotoxic, antibacterial, antimalarial, and antiviral activities. ${ }^{6}$

Epipolythiodioxopiperazine (ETP) alkaloids, with either polysulphide bridges or thiomethyl groups, represent an important family of bioactive secondary metabolites, which are toxic to cancer cell lines. ${ }^{7}$ About 20 ETPs have been identified in the Chaetomium genus. ${ }^{6}$ During our search for novel and bioactive compounds from microorganisms, ${ }^{8-10}$ we identified the endophytic fungus, Chaetomium globosum 7951, which has cytotoxic activity towards human breast cancer cell lines. Chaetomium globosum 7951 comes from the root of Panax notoginseng, a traditional Chinese medicine.

\footnotetext{
${ }^{a}$ School of Life Science and Biopharmaceutics, Shenyang Pharmaceutical University, Shenyang 110016, China. E-mail: zhangyxzsh@163.com

${ }^{b}$ Institute of Medicinal Biotechnology, Chinese Academy of Medical Sciences, Peking Union Medical College, Beijing 100050, China. E-mail: mingsunlight@sina.com; sisyimb@hotmail.com

'Key Laboratory for Uighur Medicine, Institute of Materia Medica of Xinjiang Uygur Autonomous Region, Urumqi 830004, China

$\dagger$ Electronic supplementary information (ESI) available: 1D, 2D NMR, HRESIMS and IR spectra for compounds 1, 3, and 6. See DOI: 10.1039/c9ra02647a

\$ These authors have contributed equally to this work.
}

Chemical investigations of the solid fermentation of the Chaetomium globosum 7951 strain led to the identification of 2 new ETP alkaloids, 3 known analogs, and a new pyridine benzamide. Herein, the isolation, structural determination, and cytotoxicity of these compounds are described.

\section{Results and discussion}

The molecular formula of compound $\mathbf{1}$, a white amorphous powder, is $\mathrm{C}_{32} \mathrm{H}_{34} \mathrm{~N}_{6} \mathrm{O}_{6} \mathrm{~S}_{4}$ according to the (+)-HRESIMS data, with 19 degrees of unsaturation. The IR spectrum displayed the hydroxy or amino (3359 $\left.\mathrm{cm}^{-1}\right)$, methyl $\left(2921 \mathrm{~cm}^{-1}\right)$, and carbonyl $\left(1680 \mathrm{~cm}^{-1}\right)$ functionalities. The ${ }^{1} \mathrm{H}$ NMR spectrum (Table 1) showed two ortho-disubstituted benzene rings at $\delta_{\mathrm{H}} 6.72(1 \mathrm{H}, \mathrm{d})$, $6.77(1 \mathrm{H}, \mathrm{t}), 7.03(1 \mathrm{H}, \mathrm{t}), 7.08(1 \mathrm{H}, \mathrm{t}), 7.17(1 \mathrm{H}, \mathrm{t}), 7.22(1 \mathrm{H}, \mathrm{d}), 7.50$ $(1 \mathrm{H}, \mathrm{d})$ and $7.63(1 \mathrm{H}, \mathrm{d})$, and a trisubstituted double bond at $\delta_{\mathrm{H}}$ $7.07(1 \mathrm{H}, \mathrm{s})$ in the lower field. In addition, four methylene groups $\left(\delta_{\mathrm{H}} 3.61,3.04,4.04,3.21,4.21,4.32,3.73\right.$, and 3.43), one methine group $\left(\delta_{\mathrm{H}} 6.07\right)$, and four isolated methyl groups $\left(\delta_{\mathrm{H}} 2.12,2.28\right.$, 2.77, and 3.11) were observed in the higher field. According to the ${ }^{13} \mathrm{C}$ NMR and DEPT spectra analyses, in addition to the structural features above, there were also four carbonyls at $\delta_{\mathrm{C}} 161.1,164.3$, 165.3 , and 165.6 , and five quaternary carbons at $\delta_{\mathrm{C}} 65.0,72.9,73.2$, 73.7, and 77.2. The spectral data, combined with the molecular formula, suggested that compound $\mathbf{1}$ is an analog of epipolythiodioxopiperazine. Extensive analysis of the NMR data indicates similarities in chemical shifts to chaetocochin $\mathrm{C}^{\mathbf{1 1}}$ including the absence of one methyl group in 1. HMBC correlations of $\mathrm{N} H-5^{\prime}$ with $\mathrm{C}-1^{\prime}, \mathrm{C}-3^{\prime}, \mathrm{C}-4^{\prime}, \mathrm{C}-5^{\prime}$, and $\mathrm{C}-6^{\prime}$, and of $\mathrm{N}^{-} \mathrm{CH}_{3}-2^{\prime}$ with $\mathrm{C}-1^{\prime}$, and $\mathrm{C}-3^{\prime}$ indicated that $\mathrm{N}^{-\mathrm{CH}_{3}-5^{\prime}}$ in chaetocochin $\mathrm{C}$ was replaced by $\mathrm{N} H$ in 1 . The ROESY correlations of $\mathrm{H}-5$ with $\mathrm{H}-9^{\prime}$, and of $3^{\prime}$-S-Me with $6^{\prime}$-S-Me, combined with the CD effects at $\lambda_{\max } \mathrm{nm}$ $(\Delta \varepsilon) 240(+7.2), 274(-0.89)$ and $305(+3.6),{ }^{11}$ and based on the similar biogenetic perspective of chaetocochin $\mathrm{C}$, which revealed the absolute configuration of $\mathbf{1}$ was shown in Fig. 1. 
Table 1 NMR spectroscopic data of 1 and $3^{a}$

\begin{tabular}{|c|c|c|c|c|c|}
\hline \multirow[b]{2}{*}{ No. } & \multicolumn{2}{|l|}{1} & \multirow[b]{2}{*}{ No. } & \multicolumn{2}{|l|}{3} \\
\hline & $\delta_{\mathrm{H}}$ & $\delta_{\mathrm{C}}$, type & & $\delta_{\mathrm{H}}$ & $\delta_{\mathrm{C}}$, type \\
\hline 2-N-Me & $3.11, \mathrm{~s}$ & 27.7, $\mathrm{CH}_{3}$ & 2-N-OMe & $3.65, \mathrm{~s}$ & $61.0, \mathrm{CH}_{3}$ \\
\hline 3 & & $77.2, \mathrm{C}$ & 3 & $4.36, \mathrm{t}(2.4)$ & $63.5, \mathrm{CH}$ \\
\hline 4 & & 161.1, C & 4 & & 165.1, C \\
\hline 7 & $6.72, \mathrm{~d}(7.8)$ & $110.1, \mathrm{CH}$ & 6-S-Me & $2.13, \mathrm{~s}$ & $12.5, \mathrm{C}$ \\
\hline 8 & $7.17, \mathrm{t}(7.8)$ & $130.5, \mathrm{CH}$ & 7 & $3.58, \mathrm{~d}(14.4)$ & $33.7, \mathrm{CH}_{2}$ \\
\hline 9 & $6.77, \mathrm{t}(7.8)$ & $118.8, \mathrm{CH}$ & & $3.20, \mathrm{~d}(14.4)$ & \\
\hline 10 & $7.50, \mathrm{~d}(7.8)$ & $125.9, \mathrm{CH}$ & 8 & & 107.2, C \\
\hline $10 \mathrm{a}$ & & 126.9, C & 9 & $7.19, \mathrm{~d}(2.4)$ & 125.0, CH \\
\hline $10 \mathrm{~b}$ & & $73.2, \mathrm{C}$ & $\mathrm{NH}-10$ & $10.90, \mathrm{~s}$ & \\
\hline & 4.21, dd $(12.6,6)$ & & 14 & $7.58, \mathrm{~d}(7.8)$ & $118.9, \mathrm{CH}$ \\
\hline $\mathrm{OH}-13$ & $5.93, \mathrm{t}(6)$ & & $14 a$ & & $127.9, \mathrm{C}$ \\
\hline $1^{\prime}$ & & 165.6, C & 15 & $3.58, \mathrm{ov}^{b}$ & $58.5, \mathrm{CH}_{2}$ \\
\hline $2^{\prime}-\mathrm{N}-\mathrm{Me}$ & $2.77, \mathrm{~s}$ & 28.4, $\mathrm{CH}_{3}$ & $\mathrm{OH}-15$ & $4.93, \mathrm{t}(5.4)$ & \\
\hline $3^{\prime}$ & & $72.9, \mathrm{C}$ & & & \\
\hline 3'-S-Me & $2.12, \mathrm{~s}$ & $12.3, \mathrm{CH}_{3}$ & & & \\
\hline $4^{\prime}$ & & $164.3, \mathrm{C}$ & & & \\
\hline $\mathrm{NH}-5^{\prime}$ & $9.06, \mathrm{~s}$ & & & & \\
\hline $6^{\prime}$ & & $65.0, \mathrm{C}$ & & & \\
\hline $6^{\prime}-\mathrm{S}-\mathrm{Me}$ & $2.28, \mathrm{~s}$ & $13.9, \mathrm{CH}_{3}$ & & & \\
\hline $7^{\prime}$ & $3.61, \mathrm{~d}(15.4)$ & $33.9, \mathrm{CH}_{2}$ & & & \\
\hline & 3.04, d (15.4) & & & & \\
\hline $8^{\prime}$ & & $107.4, \mathrm{C}$ & & & \\
\hline & 3.43, dd $(10.8,4.8)$ & & & & \\
\hline $\mathrm{OH}-15^{\prime}$ & $4.90, \mathrm{t}(6)$ & & & & \\
\hline
\end{tabular}

${ }^{a} \mathrm{NMR}$ data $(\delta)$ were measured at $600 \mathrm{MHz}$ for ${ }^{1} \mathrm{H}$ and at $150 \mathrm{MHz}$ for ${ }^{13} \mathrm{C}$ in DMSO- $d_{6}$. The assignments were based on ${ }^{1} \mathrm{H}-{ }^{1} \mathrm{H}$ COSY, HSQC, and HMBC experiments. ${ }^{b} J$-value was not determined due to overlapped signals.

The molecular formula of compound 3 is $\mathrm{C}_{16} \mathrm{H}_{19} \mathrm{~N}_{3} \mathrm{O}_{4} \mathrm{~S}$ according to the HRESIMS data. The IR spectrum displayed absorptions bands at 3393, 3194, 2921, and $1675 \mathrm{~cm}^{-1}$, suggesting the presence of amino or hydroxyl, methyl, and carbonyl groups. The ${ }^{1} \mathrm{H}$-NMR spectrum (Table 1) showed 3-substituted indole moiety signals at $\delta_{\mathrm{H}} 6.94(1 \mathrm{H}, \mathrm{t}), 7.02(1 \mathrm{H}, \mathrm{t}), 7.19(1 \mathrm{H}, \mathrm{d})$, $7.29(1 \mathrm{H}, \mathrm{d})$ and $7.58(1 \mathrm{H}, \mathrm{d})$, two methylene groups at $\delta_{\mathrm{H}} 3.58$ $(1 \mathrm{H}, \mathrm{d}), 3.20(1 \mathrm{H}, \mathrm{d})$, and $3.56(2 \mathrm{H}, \mathrm{m})$, a methine group at $\delta_{\mathrm{H}}$ $4.36(1 \mathrm{H}, \mathrm{t})$, one isolated methyl at $\delta_{\mathrm{H}} 2.13(3 \mathrm{H}, \mathrm{s})$, and a methoxyl group at $3.65(3 \mathrm{H}, \mathrm{s})$. In addition, two carbonyls at $\delta_{\mathrm{C}}$ 162.7 and 165.1, and a quaternary carbon at $\delta_{\mathrm{C}} 66.7$ were identified via the ${ }^{13} \mathrm{C}-\mathrm{NMR}$ spectrum. HMBC correlations of $\mathrm{H}-7$ with C-7, C-8, and C-10a; NH-5 $\left(\delta_{\mathrm{H}} 8.58\right)$ with C-1, C-6, and C-7; and S-Me- 6 with C-6, revealed an $\alpha$-S-methyl-substituted tryptophan residue. In addition, ${ }^{1} \mathrm{H}-{ }^{1} \mathrm{H}$ COSY relationships between
$\mathrm{H}-3 / \mathrm{H}_{2}-15 / \mathrm{OH}-15$, in combination with the HMBC relationships between $\mathrm{H}-3$ and $\mathrm{H}-15$ with $\mathrm{C}-16$, indicate a serine residue. Meanwhile, the association of NH-5 with C-3 and H-3 with C-1 in the HMBC spectrum suggests that the serine and tryptophan residues form a diketopiperazine ring. Finally, the methoxyl group is located at $\mathrm{N}-3$, as indicated by the molecular formula and the chemical shift at $\delta_{\mathrm{C}}$ 61.0. Thus, compound 3 was proposed as shown in Fig. 2. DP4+ analysis of the ${ }^{1} \mathrm{H}$ and ${ }^{13} \mathrm{C}$ NMR data indicates $3 S^{*}, 6 S^{*}-3$ appeared agreement with the experimental NMR data with $100 \%$ probability (Tables S3$\mathrm{S} 7 \dagger){ }^{12,13}$ Based on the common biosynthetic origin, the absolute configuration at C-3 and C-6 is probably to be the same as cycloL-Trp-L-Ser. ${ }^{14}$ In addition, the calculated optical rotation (OR) value $^{8}(+56.1)$ of $(3 S, 6 S)$-3 (Table S8 $\dagger$ ) is similar to the experiment OR value (+80.0), which supports the above speculation. 

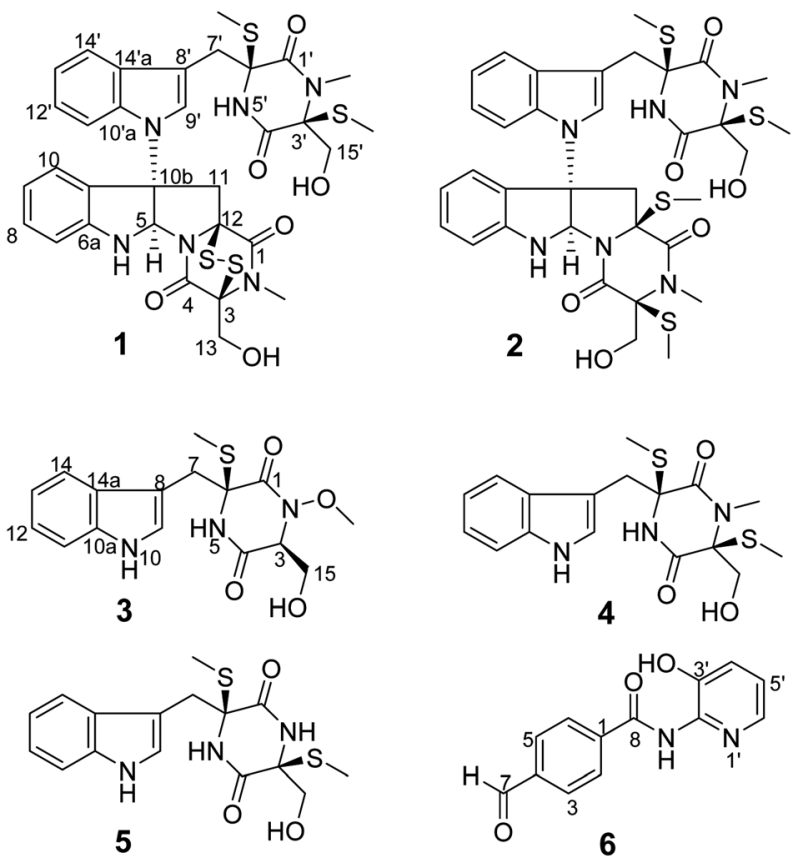

Fig. 1 The structures of compounds 1-6.

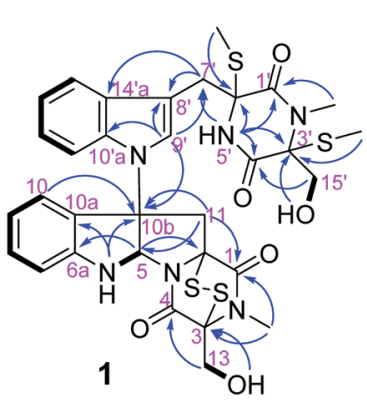

- ${ }^{1} \mathrm{H}^{1} \mathrm{H} \cos Y$

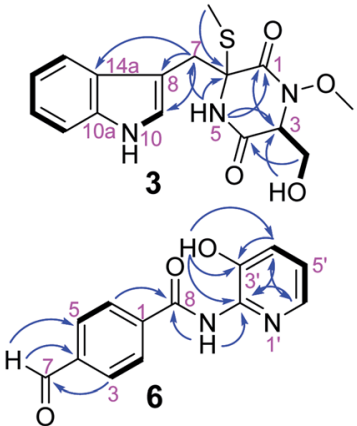

$\frown \mathrm{HMBC}$
Fig. 2 Key ${ }^{1} \mathrm{H}-{ }^{1} \mathrm{H}$ COSY and $\mathrm{HMBC}$ correlations of 1, 3 and 6 .

The molecular formula of compound $\mathbf{6}$, a white amorphous powder, is $\mathrm{C}_{13} \mathrm{H}_{10} \mathrm{~N}_{2} \mathrm{O}_{3}$, in accordance with the HRESIMS at $m / z$ 243.0769 $[\mathrm{M}+\mathrm{H}]^{+}$(calculated for $\mathrm{C}_{13} \mathrm{H}_{11} \mathrm{~N}_{2} \mathrm{O}_{3}, 243.0770$ ). Amino or hydroxyl $\left(3388,3189 \mathrm{~cm}^{-1}\right)$, conjugated carbonyl (1690 $\left.\mathrm{cm}^{-1}\right)$, and aromatic ring $\left(1621,1556\right.$, and $\left.1453 \mathrm{~cm}^{-1}\right)$ groups were observed in the IR spectrum. The ${ }^{1} \mathrm{H}-\mathrm{NMR}$ spectrum (Table 2) suggests a para-substituted phenyl at $\delta_{\mathrm{H}} 8.03(2 \mathrm{H}$, d) and $8.17(2 \mathrm{H}, \mathrm{d})$. Three aromatic proton signals at $\delta_{\mathrm{H}} 7.21$ $(1 \mathrm{H}, \mathrm{dd}), 7.33(1 \mathrm{H}, \mathrm{dd})$, and $7.95(1 \mathrm{H}, \mathrm{d})$ and three exchanged protons at $\delta_{\mathrm{H}} 10.64(1 \mathrm{H}, \mathrm{s}), 10.10(1 \mathrm{H}, \mathrm{s})$, and $9.88(1 \mathrm{H}, \mathrm{s})$ are also observed in the ${ }^{1} \mathrm{H}-\mathrm{NMR}$ spectrum. HMBC relationships of $\mathrm{H}-7$ with $\mathrm{C}-3$ and $\mathrm{C}-5, \mathrm{H}-2$ and $\mathrm{H}-6$ with $\mathrm{C}-10$, and $\mathrm{NH}-8$ with C-8 suggest a 4 -formylbenzamide unit in 6. The ${ }^{1} \mathrm{H}-{ }^{1} \mathrm{H}$ COSY correlations display an isolated spin system as $\mathrm{H}-4^{\prime} / \mathrm{H}-5^{\prime} / \mathrm{H}-6^{\prime}$. Meanwhile, the HMBC relationships of $\mathrm{H}-6^{\prime}$ with $\mathrm{C}-2^{\prime}$ and $\mathrm{OH}-3^{\prime}$ with C-2', C-3', and C- $4^{\prime}$, combined with the molecular composition and chemical shifts, revealed a 2 -substituted pyridin-3-ol
Table 2 NMR spectroscopic data of $6^{a}$

\begin{tabular}{lll}
\hline & $\mathbf{6}$ & \\
\cline { 2 - 3 } No. & $\delta_{\mathrm{H}}$ & $\delta_{\mathrm{C}}$, type \\
\hline 1 & & $138.8, \mathrm{C}$ \\
2 & $8.17, \mathrm{~d}(8.4)$ & $128.7, \mathrm{CH}$ \\
3 & $8.03, \mathrm{~d}(8.4)$ & $129.4, \mathrm{CH}$ \\
4 & & $138.1, \mathrm{C}$ \\
5 & $8.03, \mathrm{~d}(8.4)$ & $129.4, \mathrm{CH}$ \\
6 & $8.17, \mathrm{~d}(8.4)$ & $128.7, \mathrm{CH}$ \\
7 & $10.10, \mathrm{~s}$ & $193.0, \mathrm{CH}$ \\
8 & & $165.2, \mathrm{C}$ \\
$\mathrm{NH}-8$ & $10.64, \mathrm{~s}$ & $147.7, \mathrm{C}$ \\
$2^{\prime}$ & & $139.9, \mathrm{C}$ \\
$3^{\prime}$ & & $124.7, \mathrm{CH}$ \\
$\mathrm{OH}^{\prime} 3^{\prime}$ & $9.88, \mathrm{~s}$ & $123.2, \mathrm{CH}$ \\
$4^{\prime}$ & $7.33, \mathrm{dd}(8.4,1.2)$ & $138.6, \mathrm{CH}$ \\
$5^{\prime}$ & $7.21, \mathrm{dd}(8.4,4.2)$ & \\
$6^{\prime}$ & $7.95, \mathrm{~d}(5.4)$ &
\end{tabular}

${ }^{a}$ NMR data $(\delta)$ were measured at $600 \mathrm{MHz}$ for ${ }^{1} \mathrm{H}$ and at $150 \mathrm{MHz}$ for ${ }^{13} \mathrm{C}$ in DMSO- $d_{6}$. The assignments were based on ${ }^{1} \mathrm{H}-{ }^{1} \mathrm{H}$ COSY, HSQC, and HMBC experiments.

moiety. Finally, the correlation of NH-8 with $\mathrm{C}-2^{\prime}$ in the HMBC spectrum demonstrates that the above two units are linked via $\mathrm{NH}-8$ to C-2'. Thus, compound 6 is 4 -formyl- $N$-( $3^{\prime}$-hydroxypyridin- $2^{\prime}$-yl) benzamide.

In addition to compounds $\mathbf{1}, \mathbf{3}$, and $\mathbf{6}$, the known dethiotetra(methylthio)chetomin (2), ${ }^{15}$ chetoseminudin B (4), ${ }^{16}$ and chetoseminudin C (5), ${ }^{16}$ were also isolated from the Chaetomium globosum 7951. The cytotoxic effects of these compounds against human cancer cell lines were evaluated. Compounds 13 and 6 inhibited the growth of MCF-7, MDA-MB-231, H460, and HCT- 8 cells ( $\mathrm{IC}_{50}$ from 4.5 to $65.0 \mu \mathrm{M}$ ). Compounds 4 and 5 were inactive ( $\left.\mathrm{IC}_{50}>100 \mu \mathrm{M}\right)$ (Table 3, Fig. 3).

\section{Experimental}

\section{General experimental procedures}

See the ESI. $\dagger$

\section{Microorganism and fermentation}

The fungus Chaetomium globosum 7951 was isolated from the fresh healthy roots of Panax notoginseng gathered in Wenshan,

Table 3 Cytotoxicity against human cancer cell lines of 1-6

\begin{tabular}{lllll}
\hline & $\mathrm{IC}_{50}(\mu \mathrm{M})$ & & \\
\cline { 2 - 5 } Compd. & MCF-7 & MDA-MB-231 & H460 & HCT-8 \\
\hline $\mathbf{1}$ & $20.1 \pm 2.5$ & $50.3 \pm 3.6$ & $7.0 \pm 0.8$ & $30.3 \pm 3.9$ \\
$\mathbf{2}$ & $60.5 \pm 7.0$ & $61.2 \pm 5.6$ & $9.4 \pm 0.7$ & $4.5 \pm 0.5$ \\
$\mathbf{3}$ & $30.3 \pm 2.8$ & $50.4 \pm 5.0$ & $65.0 \pm 6.0$ & $41.9 \pm 5.0$ \\
$\mathbf{4}$ & $>100$ & $>100$ & $>100$ & $>100$ \\
$\mathbf{5}$ & $>100$ & $>100$ & $>100$ & $>100$ \\
$\mathbf{6}$ & $18.0 \pm 1.5$ & $25.2 \pm 2.8$ & $>100$ & $>100$ \\
Cisplatin & $36.0 \pm 3.0$ & $28.0 \pm 3.0$ & $9.0 \pm 0.6$ & $3.5 \pm 0.2$ \\
Doxorubicin & $0.5 \pm 0.02$ & $0.3 \pm 0.03$ & $6.2 \pm 0.3$ & $0.3 \pm 0.02$
\end{tabular}



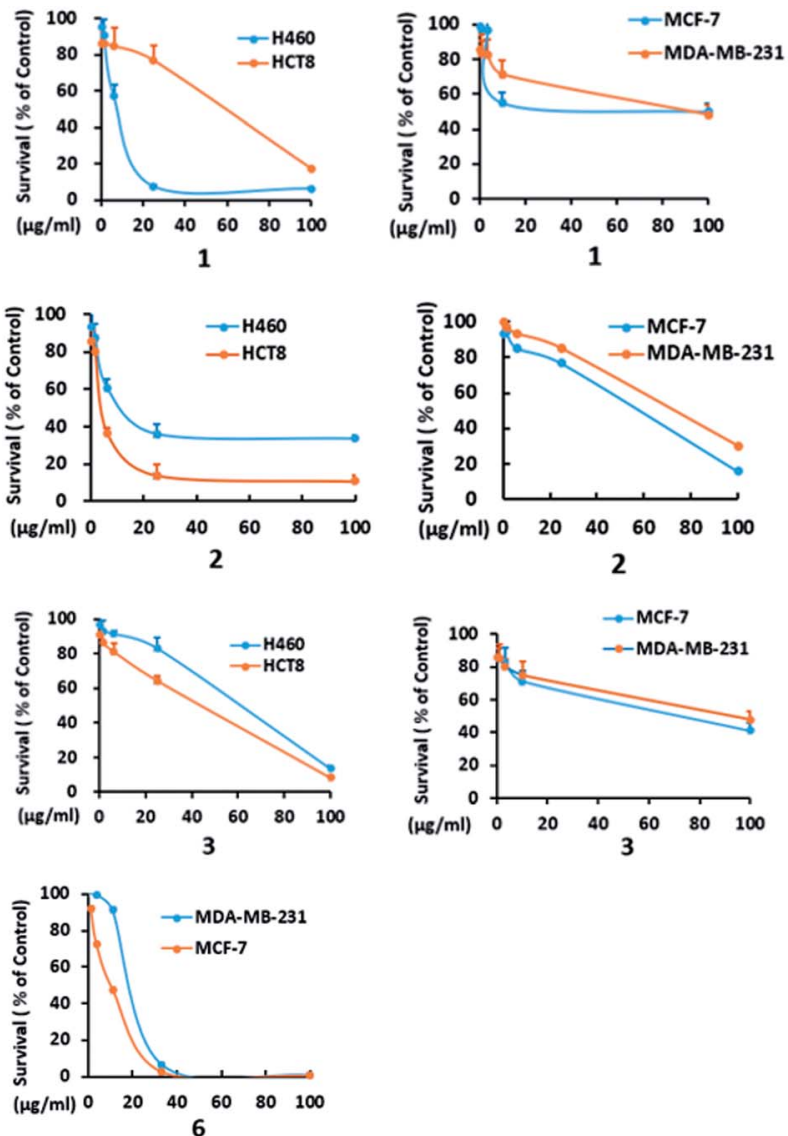

Fig. $3 \mathrm{H} 460, \mathrm{HCT} 8, \mathrm{MCF}-7$ and MDA-MB-231 cells were treated with the indicated concentrations of $1-3$ and 6 , and cell survival was detected by the CCK8 assay. A dose-dependent curve was depicted.

Yunnan Province, China, in 2015. The strain, which was assigned the accession no. SUB5310227, was identified using nuclear 18S rDNA sequences (GenBank: MK625020) and deposited in the Microbiology Laboratory at Shenyang Pharmaceutical University. C. globosum 7951, an endophytic fungus, was grown on PDA at $26{ }^{\circ} \mathrm{C}$ for 6 days, and then flushed (sterilized water) into $250 \mathrm{ml}$ Erlenmeyer flasks containing $50 \mathrm{~g}$ rice and autoclaved $\left(121{ }^{\circ} \mathrm{C}, 30 \mathrm{~min}\right)$. The fermentation was then incubated at $26{ }^{\circ} \mathrm{C}$ for 40 days.

\section{Extraction and isolation}

The cultures $(10 \mathrm{~kg})$ were extracted three times with methanol and then filtered. The filtrate was concentrated and three extractions were performed with equal volumes of EtOAc. The EtOAc layer was evaporated with reduced pressure resulting in a crude broth extract (12.2 g). The extract was separated into 15 fractions (A-O) using silica gel column chromatography with a $\mathrm{CH}_{2} \mathrm{Cl}_{2} / \mathrm{MeOH}$ gradient elution. Fraction $\mathrm{H}$ was purified using Sephadex LH-20 gel column chromatography with $\mathrm{CH}_{2} \mathrm{Cl}_{2}$ / $\mathrm{MeOH}(1: 1)$, resulting in subfractions H1-H8. Subfraction H5 was subjected to semi-preparative HPLC with 50\% acetonitrile elution into $0.1 \%$ trifluoroacetic acid to isolate compound 1 . Fraction $\mathrm{J}$ was purified by ODS $\mathrm{C}_{18}$ with a gradient of methanol in water (10-100\%) to give six subfractions (J1-J6). Subfraction
J3 was subjected to preparative TLC using $\mathrm{CH}_{2} \mathrm{Cl}_{2} / \mathrm{MeOH}(20: 1)$ and then subjected to semi-preparative HPLC with $30 \%$ acetonitrile $/ \mathrm{H}_{2} \mathrm{O}\left(0.1 \% \mathrm{CF}_{3} \mathrm{COOH}\right)$ as the mobile phase to generate compound 6. Fraction $\mathrm{K}$ was separated into fractions using silica gel CC with $\mathrm{CH}_{2} \mathrm{Cl}_{2} / \mathrm{MeOH}(50: 1)$, resulting in fractions K1-K3. Fraction K1 was purified with semi-preparative HPLC with $19 \%$ acetonitrile into an aqueous $0.1 \%$ trifluoroacetic acid solution, resulting in compound 3 .

Demethylchaetocochin C (1). White amorphous powder; $[\alpha]_{\mathrm{D}}^{20} 61.0$ ( $\left.c 0.3, \mathrm{MeOH}\right)$; UV $(\mathrm{MeOH}) \lambda_{\max } 219,286 \mathrm{~nm}$; IR $\nu_{\max }$ 3359, 3193, 2921, 2851, 1680, 1468, 1425, 1207, 1140, 1061, 1027, $722 \mathrm{~cm}^{-1}$; ${ }^{1} \mathrm{H}$ NMR (DMSO- $d_{6}, 600 \mathrm{MHz}$ ) data and ${ }^{13} \mathrm{C}$ NMR (DMSO- $d_{6}, 150 \mathrm{MHz}$ ) data, see Table 1. (+)-HR-ESIMS $\mathrm{m} / z$ 727.1499 $[\mathrm{M}+\mathrm{H}]^{+}$(calcd for $\mathrm{C}_{32} \mathrm{H}_{35} \mathrm{~N}_{6} \mathrm{O}_{6} \mathrm{~S}_{4}, 727.1501$ ).

Chaetoperazine A (3). White amorphous powder; $[\alpha]_{\mathrm{D}}^{20} 80.0(c$ 0.3, MeOH); UV (MeOH) $\lambda_{\max }$ 199, $273 \mathrm{~nm}$; IR $\nu_{\max } 3393,3194$, 2922, 2850, 1675, 1424, 1205, 1141, 801, 749, $723 \mathrm{~cm}^{-1}$; ${ }^{1} \mathrm{H}$ NMR (DMSO- $d_{6}, 600 \mathrm{MHz}$ ) data and ${ }^{13} \mathrm{C}$ NMR (DMSO- $d_{6}, 150 \mathrm{MHz}$ ) data, see Table 1. (+)-HR-ESIMS $m / z$ 372.0994 [M + Na] ${ }^{+}$(calcd for $\left.\mathrm{C}_{16} \mathrm{H}_{19} \mathrm{~N}_{3} \mathrm{O}_{4} \mathrm{NaS}, 372.0994\right)$.

4-Formyl-N-(3'-hydroxypyridin-2'-yl) benzamide (6). White amorphous powder; UV (MeOH) $\lambda_{\max } 254,325 \mathrm{~nm}$; IR $\nu_{\max } 3388$, 3189, 2921, 2850, 1690, 1621, 1556, 1453, 1387, 1320, 1210, 1142, 1052, 1029, 1011, 838, $724 \mathrm{~cm}^{-1} ;{ }^{1} \mathrm{H}$ NMR (DMSO- $d_{6}, 600$ $\mathrm{MHz}$ ) data and ${ }^{13} \mathrm{C}$ NMR (DMSO- $d_{6}, 150 \mathrm{MHz}$ ) data, see Table 2. (+)-HR-ESIMS $m / z 243.0769[\mathrm{M}+\mathrm{H}]^{+}$(calcd for $\mathrm{C}_{13} \mathrm{H}_{11} \mathrm{~N}_{2} \mathrm{O}_{3}$, 243.0770).

\section{ORs and NMR calculation of 3}

See the ESI. $\dagger$

\section{Cytotoxicity assay}

A CCK colorimetric assay was used to measure the cytotoxicity of compounds 1-6 was in human breast adenocarcinoma cell (MCF-7 and MDA-MB-231), human large cell lung cancer cell (H460) and human cecal adenocarcinoma cell (HCT-8). All of the cell lines were obtained from ATCC. Cells $\left(5 \times 10^{3}\right.$ cells per $\mathrm{mL}$ ) were added to 96-well culture dishes and grown for $24 \mathrm{~h}$ $\left(5 \% \mathrm{CO}_{2}, 37^{\circ} \mathrm{C}\right)$ followed by the addition of fresh medium (100 $\mu \mathrm{L})$ and the test compound. After an additional $48 \mathrm{~h}$, the media was removed and fresh media with $10 \%$ CCK solution was added. The cells were incubated for $1 \mathrm{~h}\left(37^{\circ} \mathrm{C}\right)$ and then the optical density at $450 \mathrm{~nm}$ was determined. Each assay was replicated six times. $\mathrm{IC}_{50}$ values for each cell line were determined.

\section{Conclusions}

In conclusion, two new ETPs alkaloids (1, and 3), a new pyridine benzamide (6), and three known ETPs compounds were identified in the endophytic fungus Chaetomium globosum 7951. These new compounds moderately inhibit the human breast cancer cells (MCF-7 and MDA-MB-231) and human ileocecal adenocarcinoma (HCT-8) growth. The new compound 1 significantly exhibits cytotoxic against the human lung cancer cell (H460). 


\section{Conflicts of interest}

There are no conflicts to declare.

\section{Acknowledgements}

Financial support from the National Natural Science Foundation of China (NNSFC, 81302675), CAMS Innovation Fund for Medical Sciences (CIFMS, 2016-I2M-2-002, and 2018-I2M-3005), the Drug Innovation Major Project of China (Grant No. 2018ZX09735001-002 and 2018ZX09711001-007), PUMC Youth Fund and the Fundamental Research Funds for the Central Universities (3332015133), Natural Science Foundation of Beijing Municipality (7144224), and Tianshan Cedar Project in Xinjiang Uygur Autonomous Region (2017XS10).

\section{Notes and references}

1 S. E. Helaly, B. Thongbai and M. Stadler, Nat. Prod. Rep., 2018, 35, 992-1014.

2 L. Chen, Q. Y. Zhang, M. Jia, Q. L. Ming, W. Yue, K. Rahman, L. P. Qin and T. Han, Crit. Rev. Microbiol., 2016, 42, 454-473.

3 H. Nisa, A. N. Kamili, I. A. Nawchoo, S. Shafi, N. Shameem and S. A. Bandh, Microb. Pathog., 2015, 82, 50-59.

4 N. Fatima, S. A. Muhammad, I. Khan, M. A. Qazi, I. Shahzadi, A. Mumtaz, M. A. Hashmi, A. K. Khan and T. Ismail, Acta Physiol. Plant., 2016, 38, 136.

5 S. Sekita, K. Yoshihira, S. Natori and H. Kuwano, Tetrahedron Lett., 1973, 14, 2109-2112.
6 Q. Zhang, H. Q. Li, S. C. Zong, J. M. Gao and A. L. Zhang, Mini Rev. Med. Chem., 2012, 12, 127-148.

7 C. S. Jiang and Y. W. Guo, Mini Rev. Med. Chem., 2011, 11, 728-745.

8 M. Chen, R. Wang, W. Zhao, L. Yu, C. Zhang, S. Chang, Y. Li, T. Zhang, J. Xing, M. Gan, F. Feng and S. Si, Org. Lett., 2019, 21, 1530-1533.

9 M.-H. Chen, S.-S. Chang, B. Dong, L.-Y. Yu, Y.-X. Wu, R.-Z. Wang, W. Jiang, Z.-P. Gao and S.-Y. Si, RSC Adv., 2018, 8, 5138-5144.

10 M. Chen, Y. Wu, Y. He, Y. Xu, Y. Li, D. Li, T. Feng, L. Yu, B. Hong, W. Jiang and S. Si, Bioorg. Med. Chem. Lett., 2015, 25, 562-565.

11 G. Y. Li, B. G. Li, T. Yang, J. F. Yan, G. Y. Liu and G. L. Zhang, J. Nat. Prod., 2006, 69, 1374-1376.

12 N. Grimblat, M. M. Zanardi and A. M. Sarotti, J. Org. Chem., 2015, 80, 12526-12534.

13 Y. N. Wang, G. Y. Xia, L. Y. Wang, G. B. Ge, H. W. Zhang, J. F. Zhang, Y. Z. Wu and S. Lin, Org. Lett., 2018, 20, 73417344.

14 L. Li, D. Li, Y. Luan, Q. Gu and T. Zhu, J. Nat. Prod., 2012, 75, 920-927.

15 I. Marmouzi, M. El Abbes Faouzi, N. Saidi, Y. Cherrah, N. Rehberg, S. S. Ebada, W. Ebrahim, R. Kalscheuer and P. Proksch, Chem. Nat. Compd., 2017, 53, 1208-1211.

16 H. Fujimoto, M. Sumino, E. Okuyama and M. Ishibashi, J. Nat. Prod., 2004, 67, 98-102. 